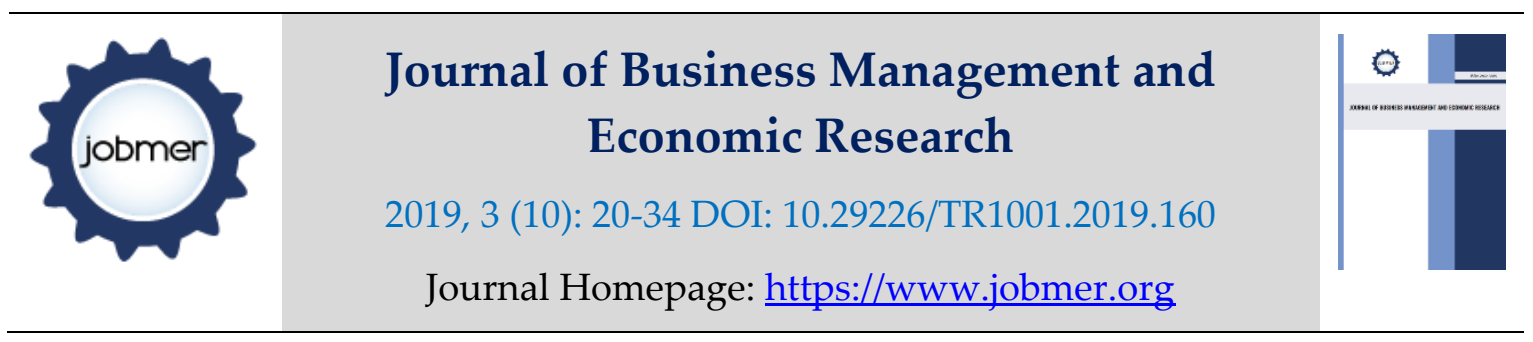

\title{
Socially Sustainable Supply Chain Practices on Firm Performance. Does Organisation Culture Matters? Evidence from Manufacturing Firms in Kenya
}

\section{Zurah Chepkoech Mohammed}

mohammedzurah6@gmail.com

\section{Vincent Ngeno}

\begin{abstract}
The main purpose of the study was to determine mediating effect of organization culture on the socially sustainable supply chain practices and performance of manufacturing firms. Using a survey of 281 Kenyan manufacturing firms the study tested hypotheses using PLSbootstrapping Structural Equation Modeling (SEM). From the SEM model, the results revealed that organization culture partially mediates the relationship between socially sustainable supply chain practices on performance of manufacturing firms $(\beta=.728, p<.05)$. The study also concluded that for socially sustainable practices there are other underlying factors affecting the performance of manufacturing firms apart from the organization culture. This study hence contributes to sustainable supply chain management literature by the inclusion of organizational culture and also extends resource based theory, natural resource based theory and stakeholder theories of a firm. The study recommended a further study on effect of organization culture and social sustainability practices
\end{abstract}

Keywords: Organization Culture, Socially Sustainable Supply Chain Practices, Performance, Manufacturing Firms

\section{Introduction}

Firm performance is the institution's capability to achieve its objectives by means of resources in a well-organized and effective way (Conferring to Fauzi et al. 2010). Measuring the performance of an organization as posited out by Huber (2004) ensures that strategic activities are aligned to the strategic plan further improving the bottom line by reducing process cost and improving productivity and mission effectiveness. In the competitive worldwide surrounding, the performance of a firm can no lengthier only be established by the choices and activities that take place inside a company; rather it will rely on the implementation of choices and activities 
engaged in its whole supply chain (Naslund \& Williamson, 2010). Performance of industrial companies in relative to sustainable supply chain practices has been thinly published.

Gold et al., (2010) suggested that when endeavoring for sustainability, a company and its supply chain ought to both possess all the necessary interior resources to execute sustainable supply chain management (SSCM) methods. Ageron et al., (2012) suggested a conceptual theory for SSCM elucidating the causes, characteristics, and obstacles for embracing SSCM via SSCM methods. Beske (2012) built a context of incorporating SSCM methods and dynamic abilities by a serious examination of collected works. Morali and Searcy (2013) concentrated on SSCM methods used in Canadian manufacturing and addressed the problems encountered throughout its execution for attaining sustainability. Glover et al., (2014) inspected the degree of SSCM methods executed in the food industry centered on Institutional Model. Pressures that force the companies to embrace maintainable methods in their corporate strategies were also inspected.

Social factors in supply chains are described by Klassen and Vereecke $(2012$, p. 103) as "merchandise or procedure connected aspects of functions that impact human protection, wellbeing and society growth" and this description has remained backed up by Marshall et al., (2015) and Sarkis (2012) as social methods concentrates on the health and welfare of persons in the supply chain and effects on community. The administration of social matters comprises choices that avoid a company from embracing unprincipled practices and pampering in communally improper practices. Nevertheless, what makes up a social matter significantly contrasts amongst dissimilar stakeholders since they continually alter and are reliant on circumstances under which a company is functioning (Hoejmoseet al. 2013b, 2014; Clarkson 1995).

Organizational culture is recognized to be vital to institutions' achievement (Balthazard, Cooke, \& Potter, 2006; Chan, Shaffer, \& Snape, 2004; Denison, 1990; Denison \& Mishra, 1995; Kotter \& Heskett, 1992; Wilderom, Glunk, \& Maslowski, 2000). A robust organizational culture enables great heights of staff drive and commitment (Sheridan, 1992; Virtanen, 2000), intention to stay with the firm (Lok \& Crawford, 1999, 2004; Lund, 2003; MacIntosh \& Doherty, 2005; Schwepker, 2001), and teamwork (Goffee \& Jones, 1996). The writings have shown some administrative values, attitudes, behaviour and cultural magnitudes which scholars call to be significance for institutions to become maintainable. These, successfully comprise an institution's culture (Denison, 1990; Gordon \& DiTomaso, 1992; Schein, 2004). Nevertheless, comparatively few 
studies has stood assumed to comprehend the exact nature of such a culture, its existence in greatly maintainable institutions, or in institutions which are enthusiastically striving to become more maintainable, or, its influence on an institution's motivation towards sustainability. Thus the study hypothesized that.

Ha: Socially sustainable supply chain practices positively affect performance through organization culture

\section{Review of Literature and Theories}

The social measurement evaluates supply chain participants (e.g. societies, staffs and clients) inside four key pointers. These are client gratification, worker contentment, noise contamination, health and safety (Gunasekaran, et al., 2004; Adel El-Baz, 2011; Gopalakrishnan, et al., 2012; Grigoroudis, et al., 2012, Govindan, et al., 2013). Consumer gratification is a yield quantity. A client grievance is a metric used to quantify client gratification. Consumer reply time or request cycle time quantifies the amount of time amid a request and its corresponding supply. Furthermore, worker contentment is inside the field of human resource management that influences corporate undertakings. The responsibility of human resource is to measure human productivity by human abilities, labor productivity (Freeman, 2008). Yawaar and Seuring (2015) on the contrary having given a profound comprehension of the management of social matters in supply chains. The research provided a conceptual context for handling social matters in supply chains.

Social sustainability in the supply chain can be narrowed down to the product and process measures that determine the safety and welfare of the people in the chain. To understand better, we can still elaborate that how these human and social issues are managed in the supply chain that will affect the firm's sustainability. According to Wood (1991), one needs to understand that these social issues in the supply chain should be targeted to whom. And what stakeholder theory explains that people spread across three stages should be managed (Freeman, 1984, 2004; Walsh, 2005; Heath, 2006; Campbell, 2007). All three stages of supply chain consist of in-house operations, suppliers, customers, and the external stakeholders which includes society, and non-governmental organizations.

Many other studies were done on what enables social sustainability in the supply chain. Notable contributions from the research done by Clarkson (1995), Strong (1997a), McWilliams (2001), Ehrgott et al., (2011), in which they explored various forces, such as customer 
requirements, stakeholder requirements, employee requirements, and skillful policy entrepreneurs, economic status of corporate and their influences on social sustainability adoption. Lu et al., (2012) described ethical supplier development and its impaction corporate social performance in China. Mani et al., (2014) identified various social dimensions in the supply chain and described how these social dimensions can be effectively used in supplier selection and evaluation in India. All the scholars' more or less explored issues related to suppliers and in house operations of the manufacturing plant. However, the issues related to the downstream supply chain were explored the least.

Harris and Crane (2002), Howard Grenville (2006), and Howard Grenville, Hoffman, and Wirtenberg (2003) found that, for social initiatives to succeed, they must be aligned with an organization's core culture. Pfeffer (2010) and Pullman et al., (2009) posits that basic and advanced social sustainability supply chain practices are positively related to the strength of firm sustainability culture. Companies with social sustainability culture and mindset are more likely to engage in social sustainability practices which in turn are good for the company and good for the people inside and outside of the supply chain. According to Miska et al., (2018) on social sustainability practices and future oriented culture posited that social supply chain sustainability practices "emphasize the long-term nature of the benefit that business is expected to provide to society" (Schwartz \& Carroll, 2008, p.163). This is because sustainability aims at intergenerational equity (Bansal \& Song, 2016), and in this sense, the needs of present generations should not compromise those of future generations (Bansal \& Desjardin, 2014; Desjardins, 2016). This aligns with cultures characterized by greater future orientation practices, where long term success is valued and where organizations have a longer strategic orientation. Therefore, companies in these cultures are more likely to engage in social sustainability practices, which contribute to ensuring social justice, positive social impact, and trust among stakeholders and society in the long run. Therefore, companies in future orientation cultures are more likely to engage in social sustainability practices. Yaani Yu and Yanrok Choi (2016) posits that CSR oriented organization culture has a full mediation effect on the relationship between stakeholder pressure and adoption of CSR practices.

Organizational culture has a powerful effect on the performance and long term effectiveness of organizations. Empirical research has produced a remarkable array of findings demonstrating the importance of culture to enhance organizational performance (Cameron and Essington, 1988; Denison, 1990; Trice and Beyer, 1993). AbuJarad et al., (2010, p. 34) posits that 
organizational culture affects various employees and organization related outcomes. Organizational culture affects employee behaviour, learning and development (Bollinger \& Smith, 2001; Saeed \& Hassan, 2000), creativity and innovation (Ahmed, 1998; Martins \& Terblanche, 2003; Martins \& Martins, 2002; Mclean, 2005; Vincent et al., 2004), and knowledge management (McDermott \& Tseng, 2010). The studies related to the effect of organizational culture on performance outcomes are quite extensive (Han et al., 1998; Kim et al., 2004; Oparanma, 2010; Saeed \& Hassan, 2000; Tseng, 2010; Zain et al., 2009), yet, the results seem inconclusive (Scott et al., 2002; Qbu Jarad et al., 2010) due to definitional, structural and design related differences and problems. In addition, most studies on organization culture focus on adoption or implementation of sustainable practices and not on performance. Organization culture is a very important component for the success of sustainability initiatives. This study, therefore, investigated the mediation effect of organization culture on the relationship between social sustainable supply chain practices on the performance of manufacturing firms Kenya.

The theories that anchored this study was resource based view, stakeholder and natural resource based view. The origin of the resource-based view can be traced back to earlier research of Selznick (1957), Penrose (1959) among other researchers. The emphasis on this school of thought was on the importance of resources and its implication for the firm performance. This theory simply emphasizes the idea that an organization must be seen as a bundle of resources and capabilities to create value and therefore gain a competitive advantage (Barney, 1991). Natural resource-based view of the firm (NRBV) that posits future competitive advantage being rooted in "capabilities that facilitate environmentally sustainable economic activity" (1995).According to (Freeman, 1984).Stakeholder theory suggests that companies produce externalities that affect many parties (stakeholders) which are both internal and external to the firm. Externalities often cause stakeholders to increase pressures on companies to reduce negative impacts and increase positive ones. Socially sustainable supply chain practices are bundles of resources that contributes to competitive advantage of an organisation and it affects various stakeholders of an industrial firm.

\section{Methodology}

This study employed the explanatory survey design in positivism approach. The target population of this research was supply chain executives in industrial companies. There are nine hundred and forty manufacturing firms in Kenya categorized into different regions. A supply 
chain manager in each manufacturing firm was invited using purposive sampling to take part in the study. The study, therefore, targeted 281 respondents from the manufacturing firms. For this study, a structured questionnaire was used to collect data. For this study, the reliability of the questionnaire was tested and gave Cronbach's, of 0.987 from the pilot study conducted in the manufacturing firms in Nakuru region.

\subsection{Measurement of variables}

Socially sustainable supply chain management practices measures utilized were Fairtrade and transparency from (Bommel, 2010 ;). Females precise Issues (Ni et al., 2010,). Local purchase (Kushwaha, 2011 ;). Supply from the lesser advanced part of community (Ciliberti, 2008 ;). Society association, backing and local hiring (Pullman et al., 2010). Equity of worker and society (Markley \& Davis, 2007).Similarly, organization culture was measured by the four-dimension including organization leadership, organization glue, dominant characteristics and criteria for success developed by (Cameron and Quin, 2006). Performance of firms was measured by economic, social, environmental and operational performance developed by Hamon and Cowan (2009). All the variables were operationalized and the information was obtained from questionnaires distributed to the respondents with independence and privacy on the part of the respondents maintained.

\subsection{Analytic model}

The best method of (SEM) framework for testing indirect effects is bias-corrected bootstrapping, Shrout \& Bolger, (2002). As in all bootstrapping approaches, BC bootstrapping of the confidence intervals (CIs) for indirect effects involves taking multiple repeated samples with replacement from the data set in question. SEM process follows two steps: validating the measurement model through conducting confirmatory factor analysis and fitting the structural model through path analysis with latent variables using AMOS version 22. Kline (1998) proposed a two-step modeling process and urges SEM researchers to test the pure measurement model underlying a full structural equation model, and if the fit of the measurement model is found acceptable, then the structural model is tested. Significantly, the mediation test used for this research was based on the PLS approach, hence, the hypotheses for the study were tested using the partial least squares (PLS) structural equations modeling (SEM) technique (Wold, 1985). And mediation test is measured by means of bootstrapping 5000 re-sampling analysis in with formulated hypotheses (Hair, Ringle \& Sarstedt, 2011; Zhao, Lynch \& Chen, 2010). In addition, 
mediation is measured by multiplying the average of paths " $a$ " and " $b$ " and then dividing the obtained value by the standard error of the paths (Kock, 2013).

\section{Findings and Discussions}

This section gives the analysis, presentation, interpretation, and discussion of results on the mediating effect of organization culture on sustainable supply chain practices and performance of industrial companies in Kenya. A total of 281 questionnaires were given out from which 228 were filled and returned which represents a response rate of $81.13 \%$. The reply speed was regarded as acceptable since Nyamjom, (2013) argues that a response rate of $75 \%$ was considered excellent and a representative of the population. Before analyzing the data, it is essential to check the data and check for errors. On checking errors, the outliers were identified on each individual item and on each construct as the sum of its items. For variables with interval data, the study assigned the mean or average of the group to which the outlier belongs. Doing so, it helped almost Ten (10) cases to survive in the sample without threatening the reliability and precision of SPSS statistical procedures. Furthermore, since missing observations can be problematic, and to avoid this problem, most of the missing values were replaced with estimates computed using "mean distribution method" as recommended by Coakes and Steed (2007, p.44), therefore, generating a clean, error-free data set.

\subsection{Confirmatory Factor Analysis}

To assess the measures of the study in the proposed model, Confirmatory Factor Analysis (CFA) using Analysis of Moment Structures (AMOS) version 22.0 was performed to ensure unidimensionality, reliability, and validity of the measurement scale. The results provide an assessment of convergent and discriminant validity that determines the viability of the proposed model by assessing the factor structure. Unidimensionality is achieved when the measuring items have acceptable factor loadings for the respective latent construct. In order to ensure unidimensionality of a measurement model, any item with a low factor loading should be deleted (Zailani, 2012). The purpose of CFA is to confirm the relationship between the questions within each measure, and the proposed relationships of our model. The CFA will confirm if the measures used fit well with the data (Hair et al., 2010). Unlike Exploratory Factor Analysis (EFA), this is allowed to test our model for fit, but that does not mean that the model is the best possible for the relationships. 
The path diagram in Figure 1 displays the standardized regression weights (factor loadings) for main variables (Socially Sustainable Supply Chain Practices, Organization Culture, and Performance) and their corresponding indicators namely, SOCI 1,2; CULT 1,2,3 and PERF 1,2. and the squared multiple correlation coefficients $R^{2}$, describing the amount of variance the common factor accounts for independent, dependent and mediator variables are also displayed. The results are summarized in displayed in Figure 1 below. The results from the CFA show that our model is a good fit (Figure 1). CFI should optimally be above 0.90, and RMSEA lower than 0.07. In our model, the CFI is 0.921 , which we deem satisfactory, and the RMSEA 0.048. These results are adequate and deem the CFA satisfactory and continue the analysis. In the CFA relationships are constructed to expect rather high loadings between the constructs. Optimally loadings should be above 0.5. (Hair et al., 2006)

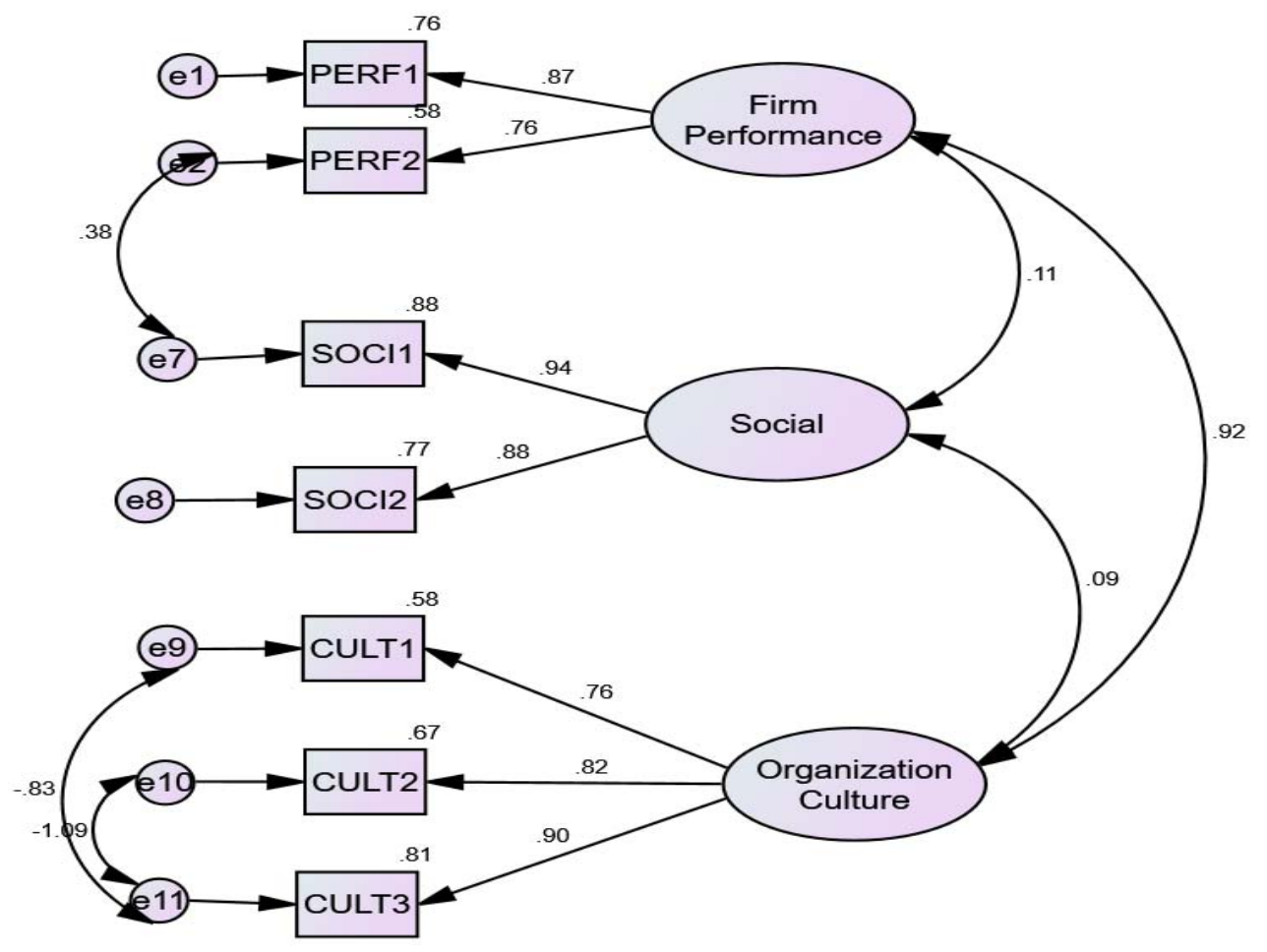

\section{Figure 1: CFA Measurement Model}

Chi square $(\chi 2)=71.667,(P<0.01)$, Normed Fit Index=.9, Comparative Fit index=.921, Tucker Lewis Index $=.917$, Root Mean Square Error of Approximation $=.048$

In this study, SEM was used to conduct mediation tests using AMOS version 22. By considering the effect of socially sustainable supply chain practices on performance of manufacturing firms, the direct effect is .434 (the path coefficient from social supply chain practices to performance) as shown in fig.2. The indirect effect, through organization culture, is computed as the product 
of the path coefficient from social supply chain practices to the organization culture and the path coefficient from organization culture to performance $\left(1.24^{*} .587=.728\right)$ as shown in Table 1 . The total effect is the sum of direct effect and indirect effect $(0.434+0.728=1.162)$.

From the results in Table 1, the indirect effect is greater $\left(1.24^{*} .587=.728\right)$ than the direct effect of .434. Thus, this research concludes that the construct organization culture is a mediator in the relationship between socially sustainable supply chain practices and performance of manufacturing firms. The type of mediation is partial mediation since the direct effect is still significant after a mediator variable was introduced in the model. The study, therefore, rejects hypothesis $\mathbf{H a}$ and concludes that the organization culture variable partially mediates the relationship between socially sustainable supply chain practices on the performance of manufacturing firms. Thus, the higher the organization culture is considered in manufacturing firms the mediation on socially sustainable supply chain practices increased with the performance of the firms.

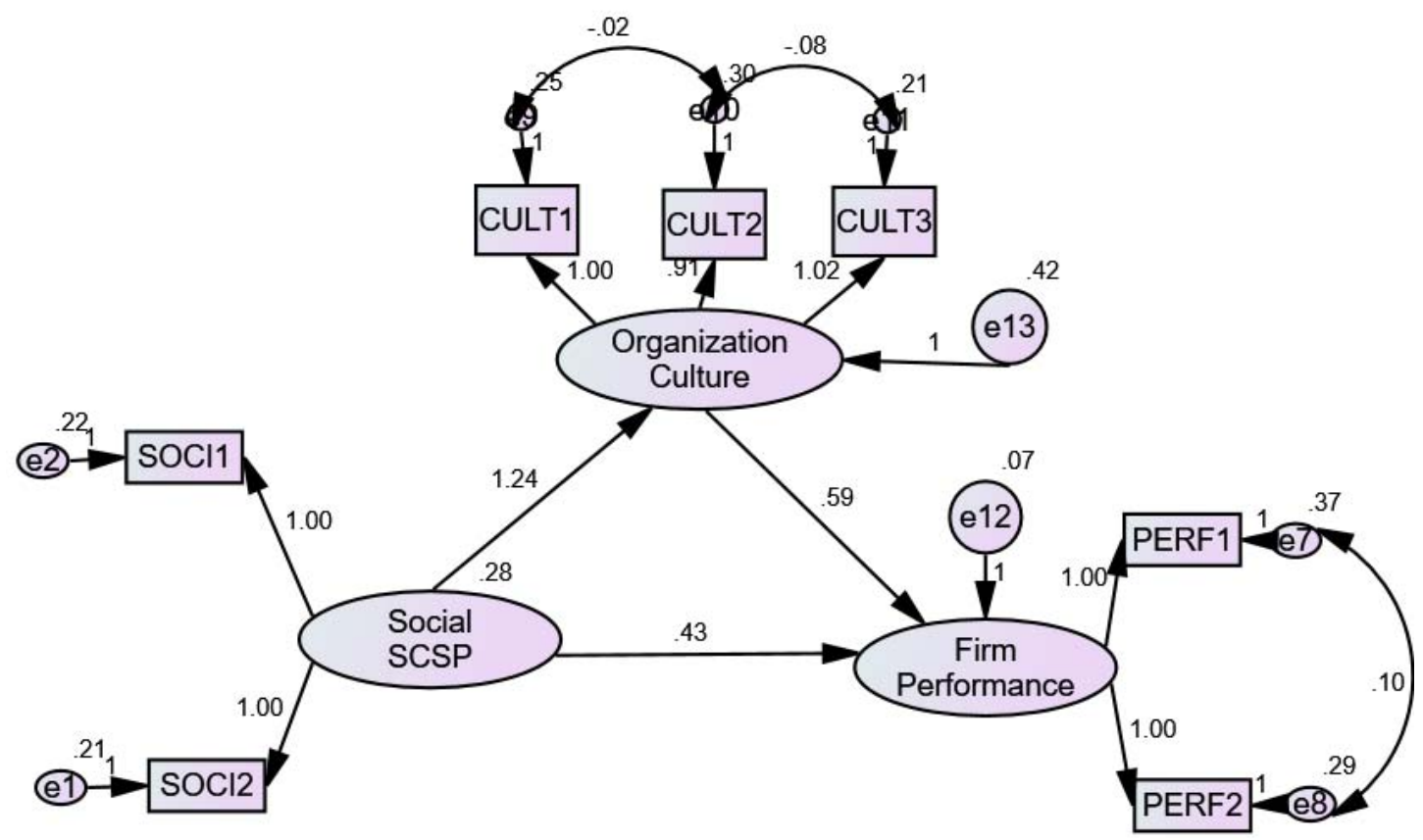

Figure 2: SEM model for Mediating Effect of Organisation Culture on Social SSCP and Firm Performance

Chi square $(\chi 2)=19.721,(P<0.01)$, Normed Fit Index=.9, Comparative Fit index=.991, Tucker Lewis Index $=.903$, Root Mean Square Error of Appropriation $=.059$, Incremental Fit Index $=.981$ 
Table 1: Total Effect, Direct Effect and Indirect Effect of Organization Culture on Socially SSCP and Firm Performance

\begin{tabular}{lllll}
\hline & & $\begin{array}{l}\text { Social } \\
\text { SCSP }\end{array}$ & $\begin{array}{l}\text { Organization } \\
\text { Culture }\end{array}$ & $\begin{array}{l}\text { Firm } \\
\text { Performance }\end{array}$ \\
\hline \multirow{3}{*}{ Total effect } & Organization & & & \\
& Culture & 1.240 & .000 & .000 \\
& Firm Performance & 1.162 & .587 & .000 \\
& Organization & & & .000 \\
Direct effect & Culture & 1.240 & .000 & .000 \\
& Firm Performance & .434 & .587 & .000 \\
& Organization & & & .000 \\
\hline \multirow{2}{*}{ Indirect effect } & Culture & .000 & .000 & .000 \\
& Firm Performance & .728 & & \\
\hline
\end{tabular}

The results indicate that organization culture partially mediates the relationship between socially SSCP and performance of manufacturing firms. This conjectures that apart from organization culture, there are other underlying factors that influence the performance of manufacturing firms. Organization culture as a mediator has a capability of carrying socially sustainable supply chain practices to influence the performance of firms but there are other factors also that researchers need to unearth that affects firm's performance in relation to socially sustainable supply chain practices. Organization culture importance in socially sustainable supply chain practices has been supported by Lee and Kim's (2017) research that claims that in order for goals to be achieved, corporate social responsibility and organizational culture need to fit each other well. According to Harris and Crane (2002), Howard-Grenville (2006), and Howard-Grenville, Hoffman, and Wirtenberg (2003) found that, for social initiatives to succeed, they must be aligned with an organization's core culture.

\section{Conclusion}

Organization culture mediates the relationship between socially sustainable supply chain practices and the performance of manufacturing firms in Kenya. In conclusion, therefore, the findings of this study show that manufacturing firms in Kenya are adopting socially sustainable supply chain practices if a strong organizational culture in that firm is in effect. Without organization culture, these practices may go unheeded. Epstein, Buhovac, and Yuthas (2010) advise that a sustainability-related culture enables organizations' decision makers to balance economic, environmental and social objectives. 
In terms of socially sustainable supply chain practices, the study established socially sustainable supply chain practices has a positive significant effect on manufacturing firm's performance. To achieve improved performance in relation to socially sustainable supply chain practices, manufacturing firms should continuously improve their working condition for all employees. This rated the highest in terms of socially sustainable practices. Corresponding to Zhu et al., (2016) revealed that social practices with a specific focus on organizational governance, human rights, and conducive environment have a significant positive impact on social performance and do not have any impact on the financial performance of a firm. They further argued that few other social practices example labour practices, supply chain, and political responsibility have a significant positive impact on firm financial performance. In addition, the manufacturing firm should support the community and have had a robust community connection and support through corporate social responsibilities activities. Moreover, manufacturing firms in Kenya should also have in their procurement, policies that target the youth, women and disabled persons all geared towards assisting disadvantaged persons as Muthury (2008) maintained that participatory approach is important in corporate community involvement for developing the capability of the local community. Harter et al., (2002) indicated that employee engagement and employee involvement have a positive impact on employee loyalty, safety and business outcomes including productivity and profit. Health and safety of all employees should also be a priority for manufacturing firms that ensure the safety and wellbeing of people working in the manufacturing sector. Manufacturing firm should also follow all legal requirements in its employment policies such as employment of underage persons, discrimination and equal opportunity for all. In terms of social practices, the firm should have a functional code of conduct that guides internal operations and relations with key suppliers and finally, the manufacturing firm should practice fair trade and transparency in all its operations whether targeting internal or external stakeholders in line with Anitha (2014); Metford (2011). When manufacturing firms in Kenya implement these socially sustainable supply chain practices, there will be improved performance.

\section{Theoretical Implication of the study}

This study further provides empirical support that organization culture mediates the relationship between socially sustainable supply chain practices on the performance of manufacturing firms in Kenya. For organization culture, the researcher concludes that organization culture is crucial for the success of sustainability initiatives of manufacturing 
firms. The organization culture variable fully mediates the relationship between social sustainable supply chain practices and performance of manufacturing firms. The more the organization culture developed in manufacturing firms the higher the environmental and economic supply chain practices influences the performance of the firms. The role of organizational culture in improving the performance of manufacturing firms through socially sustainable supply chain practices should not be neglected. The manufacturing firm should pay attention to fostering a strong organization culture geared towards sustainability if they seek to gain from sustainable supply chain practices implemented. The organization culture variable yet again partially mediates the relationship between socially sustainable supply chain practices on the performance of manufacturing firms. The more the organization culture is considered in manufacturing firms the higher the socially sustainable supply chain practices influence the performance of the firms but there are other underlying factors influencing the performance of manufacturing firms in relation to socially sustainable supply chain practices other than organization culture. Therefore, future research study should uncover what are these underlying factors influencing manufacturing firm's performance when socially sustainable supply chain practices are implemented.

\section{Practical implication}

In conclusion, manufacturing firms should pay attention to organization culture if they seek to gain from sustainable supply chain practices implementation to improve their performance. For managerial implication, the results indicate that sustainable supply chain practices have a positive effect on the performance of manufacturing firms. Thus, the manufacturing firms need to work together to share benefits and success stories of sustainable supply chain practices with other firms so as to spread and create interest in SSCM concepts across a large number of firms. In this way, supply chain managers can easily implement sustainable supply chain practices.

\section{Recommendation for Further Studies}

The study sought to determine the mediating effect of organization culture on social sustainable supply chain practices and performance of manufacturing firms, Kenya. Specifically, the study sought to establish; the effect of socially sustainable supply chain practices on performance of manufacturing companies and also test the mediation effects of organizational culture on the relationship between sustainable supply chain practices and performance of manufacturing firms. Future directions for this research should establish the mediating effect of organization culture on sustainable supply chain practices and performance of firms in the service sectors 
and draw comparisons between manufacturing sectors and service sectors and explore effects of organisation culture on socially sustainable supply chain practices.

\section{REFERENCES}

Abu-Jarad, I.S., Yusof, N.A, \& Nikbin, D. (2010). A Review Paper on Organizational Culture and Organizational Performance. International Journal of Business and Social Science, 1 (3), 2646

Ageron, B., Gunasekaran, A., \& Spalanzani, A. (2012). Sustainable supply management: An empirical study. International Journal of Production Economics, 140(1), 168-182.

Ahmed, P.K. (1998). Culture and Climate for Innovation. European Journal of Innovation Management, 1(1), 3043.

Anitha J., (2014). Determinants of employee engagement and their impact on employee performance, International Journal of Productivity and Performance Management, 63 (3) 308 323. DOI: 10.1108/IJPPM-01-2013-0008

Bansal, P., \&DesJardine, M. R. (2014). Business sustainability: It is about time. Strategic Organization, 12(1), 70-78.

Bansal, P., \& Song, H.-C. (2016). Similar but not the same: Differentiating corporate responsibility from sustainability. Academy of Management Annals, 11(1), 105-149.

Beske, P., \& Seuring, S. (2012). Putting sustainability into supply chain management. Supply Chain Management: an international journal, 19(3), 322-331.

Bollinger, A. S., \& Smith, R.D. (2001). Managing Organizational Knowledge as a Strategic Asset. Journal of Knowledge Management, 5 (1), 818.

Cameron, K. S., \& Quinn, R. E. (2006). Diagnosing and Changing Organizational Culture Based on the Competing Values Framework. Jossey-Bass, San Fransisco.

Eccles, R.G., Ioannou, I., \& Serafeim, G. (2012).The Impact of a Corporate Culture of Sustainability on Corporate Behavior and Performance. Working Paper, 12-35

Ehrgott, M., Reimann, F., Kaufmann, L. and Carter, C.R. (2011), "Social sustainability in selecting emerging economy suppliers", Journal of Business Ethics, Vol. 98 No. 1, pp. 99119.

Gold S, Seuring S, Beske P. 2010. Sustainable Supply Chain Management and InterOrganizational Resources: A Literature Review. Corporate Social Responsibility and Environmental Management 17(4): 230-245. DOI: 10.1002/csr.207

Govindan, K., Rajendran, S., Sarkis, J., \& Murugesan, P. (2013). Multi-criteria decision making approaches for green supplier evaluation and selection: a literature review. Journal of Cleaner Production.

Hoejmose, S. U., \&Adrien-Kirby, A. J. (2013b). Socially and environmentally responsible procurement: A literature review and future research agenda of a managerial issue in the 21st century. Journal of Purchasing and Supply Management, 18(4), 232-242. 
Kim, S., Lee J., \&Yu K. (2004). Corporate culture and organizational performance. Journal of Managerial Psychology, 19 (4).340 359

Klassen, R.D. and Vereecke, A. (2012), "Social issues in supply chains: Capabilities link responsibility, risk (opportunity), and performance", International Journal of Production Economics, Vol. 40 No. 1, pp. 103-115.

Kline, R.B. (1998), Principles and Practice of Structural Equation Modeling, (2nd Edition Ed.). The Guilford Press, New York.

Kotter, J.P., \&Heskett, J.L. (1992). Corporate Culture and Performance, Free Press, New York

Lok P. and Crawford J. (1999). The relationship between commitment and organizational culture, subculture,

Mani, V., R, Agrawal. V, Sharma (2014). Supplier selection using social sustainability: AHP approach in India. International Strategic Management Review, 2(2), 98-112

Marshall, D., McCarthy, L., Heavey, C., \& McGrath, P. (2015). Environmental and social supply chain management sustainability practices: construct development and measurement. Production Planning \& Control, 26(8), 673-690.

Marshall, D., McCarthy, L., McGrath, P., \&Claudy, M. (2015).Going above and beyond: how sustainability culture and entrepreneurial orientation drive social sustainability supply chain practice adoption. Supply Chain Management: An International Journal, 20(4), 434454 .

Martins, E., \& Martins, N. (2002). 'An Organisational Cultural Model to Promote Creativity and Innovation', Journal of Industrial Psychology, 28 (4), pp 58-65.

Martins, E.C., \& Terblanche, F. (2003). Building Organisational Culture that Stimulates Creativity And Innovation. European Journal of Innovation Management, 6 (1), 6474

McLean, L.D. (2005). Organization Resource Development. Advances in Developing Human Resources, 7(2), 226-246.

Morali, O., \& Searcy, C. (2013). A review of sustainable supply chain management practices in Canada. Journal of Business Ethics, 117(3), 635-658.

Nidumolu, R., C.K. Prahalad, C.K. and Rangaswami, M.R. (2009), “Why sustainability is now the key driver of innovation", Harvard Business Review, September, pp. 57-64.

Oparanma, A.O. (2010). Organizational Culture and Corporate Performance in Nigeria. International Journal of African Studies, 3, 34-40

Pagell, M. and $\mathrm{Wu}, \mathrm{S}$. (2009), "Building a more complete theory of sustainable supply chain management using case studies often exemplars", Journal of Supply Chain Management, Vol. 45 No. 2, pp. 37-56.

Pagell, M., Wu, Z. and Wasserman, M.E. (2010), "Thinking differently about purchasing portfolios: An assessment of sustainable sourcing", Journal of Supply Chain Management, Vol. 46 No. 1, pp. 57-73.

Pullman, M. E., Maloni, M. J., \& Carter, C. R. (2009). Food for thought: social versus environmental sustainability practices and performance outcomes. Journal of Supply Chain Management, 45(4), 38-54.

Saeed, M., \&Hassan, M. (2000). Organisational Culture and Work Outcomes: Evidence from some Malaysian organizations. Malaysian Management Review, 35(2), 54-59 
Sarkis, J. (2012). A boundaries and flows perspective of green supply chain management. Supply Chain Management: An International Journal, 17(2), 202-216.

Scott, T., Mannion, R., Davies, H., \& Marshall, M. (2002). The Quantitative Measurement of Organizational Culture in Health Care: A Review of the Available Instruments. Health Service Res. 38(3), 923-45.

Sharma, S. and Ruud, A. (2014) 'on the path to sustainability: integrating social dimensions into the research and practice of environmental management', Business Strategy and the Environment, Vol. 12, No. 4, pp.205-214.

Shrout, P. E., \& Bolger, N. (2002). Mediation in experimental and non-experimental studies: New procedures and recommendations. Psychological Methods, 7, 422-445.

Svensson, G. (2007), "Aspects of sustainable supply chain management (SSCM): conceptual framework and empirical example", Supply Chain Management: An International Journal, Vol. 12 No. 4, pp. 262-266.

Tseng, Shu-Mei. (2010).The correlation between organizational culture and knowledge conversion on corporate performance. Journal of Knowledge Management, 14 (2), 269-284

Vachon, S. \& Klassen, R.D., (2008). Environmental management and manufacturing performance: the role of collaboration in the supply chain. International journal of production economics, 111(2), 299-315

Vachon, S. \& Mao, Z. (2008). Linking supply chain strength to sustainable development: a country-level analysis. Journal of Cleaner Production, 16(15), 1552-1560.

Wood, D. J. (1991). Corporate social performance revisited. Academy of management review, 16(4), 691-718

Zailani, S., Jeyaraman, K., Vengadasan, G., \&Premkumar, R. (2012). Sustainable supply chain management (SSCM) in Malaysia: A survey. International Journal of Production Economics, 140(1), 330-340.

Zain, Z.M., Ihsak, R., \&Ghani E., K. (2009). The Influence of Corporate Culture on Organisational Commitment: A Study on a Malaysian Listed Company, European Journal of Economics, Finance and Administrative Sciences, 17, 17-25 